\title{
How Does Bank Competition Affect Banking Stability? The Case of an Emerging Market
}

\author{
Mo'ath Ghaleb Al-Azzam ${ }^{1} \&$ Ghada Tayem ${ }^{2}$ \\ ${ }^{1}$ M.A. Degree in Finance, the University of Jordan, Jordan \\ ${ }^{2}$ Assistant Professor in Finance, Department of Finance, School of Business, the University of Jordan, Jordan \\ Correspondence: Mo'ath Ghaleb Al-Azzam, M.A. Degree in Finance, the University of Jordan, Jordan. E-mail: \\ m3ath_alazzam@yahoo.com
}

Received: November 2, 2021

Accepted: December 16, 2022

Online Published: January 27, 2022

doi:10.5539/ijbm.v17n3p62

URL: https://doi.org/10.5539/ijbm.v17n3p62

\begin{abstract}
This paper examines the role of interbank competition on banking stability in Jordan, an emerging market. Using competition estimates measured by Lerner index, the paper examines the impact of competition on two important dimensions of banking stability, namely, credit risk and liquidity risk. The empirical results suggest that the effect of banking competition on stability differs according to the dimension of stability. After controlling for bank-level control variables and macroeconomic conditions, the empirical results of the impact of market power measured by Lerner index on credit risk show that an increase in price competition leads to more risk taking from banks. On the other hand, the impact of price competition on the second dimension of banking stability (liquidity risk) implies that an increase in price competition improves the liquidity position of banks. However, these results hold only for the sample of non-Islamic banks. Islamic banks may face wider mismatch between its assets and liabilities due to its inability to use conventional debt instruments offered by the market and hence it keeps larger cash buffers to compensate for this extra risk.
\end{abstract}

Keywords: Bank competition, Lerner Index, H-Statistics, Financial stability, Bank risk taking, Credit risk, Liquidity risk, Systemic risk, Competition policy

\section{Introduction}

The question whether there is a relationship between competition and stability in the banking system and the direction of this relationship is important especially that the prevailing view is that competition worsens stability (Keeley, 1990; Allen \& Gale, 2004). There has been a renewed interest in understanding this relationship from both an academic and policy making point of views after the recent financial crisis of 2008. This interest extends beyond large economies, such as the US, into more developing and less developing economies. Small economies suffer important losses from credit and financial crises. For example, Hoggarth and Saporta (2001) show that the fiscal cost of a financial crisis can be as high as $17 \%$ of GDP for a developing country (Note 1). Berger et al. (2004) note that despite recent studies on banking in developing countries, further research on banking stability in developing nations is still needed. Therefore, this paper contributes to the literature of the influence of bank competition on the incentives of banks to take more (alternatively less) risky actions using the context of Jordan. Understanding this trade-off provides policy makers with the knowledge needed to design and organize an efficient and sound banking system that is able to support sustainable economic growth.

Competition in the banking sector matters from policy making point of view because it can affect stability of the banking sector as there can be a trade-off between stability and increased competition through different channels. (Note 2). In terms of credit risk, higher competition leads banks to decrease lending rates charged to borrowers and hence it provids incentives for banks to take excessive risks (Hellman et al., 2000) and reduce in monitoring (Boot \& Thakor, 1993; Allen \& Gale, 2000). Inversely, competition can reduce credit risk as the decrease in lending costs can improve the credit status of borrowers as repaying loans becomes more feasible (Boyd \& De Nicolò, 2005). In addition, banks are more likely to diversify their loan portfolios in competitive environment than in less competitive one in which in turn increases bank stability (Amidu \& Wolfe, 2013).

In comparison, banks with monopoly power would exercise their ability to extract rents by charging higher loan interest rates to businesses and by paying a lower rate of return to depositors (Cetorelli, 2001). Higher lending 
rates, in turn, raise the incentives of firms to taking of excessive risky projects in order to pay this higher interest rate, thus weakening the stability of credit markets and increasing the likelihood of systemic failure (Cetorelli, 2001). Also, monopoly banks suffer from higher monitoring costs that may decrease the bank soundness and increase the probability of bank failure (Caminal \& Matutes, 2002). In contrast, banks that have higher market power due to geographical or technological specialization may have cost advantages in screening borrowers (Kaas, 2004) that may improve the average quality of banks' asset portfolios. Petersen and Rajan (1995), support the latter idea by arguing that banks with monopolistic power have lower costs of monitoring and transacting with firms.

In addition, some studies have shown that bank competition can affect banks' liquidity position. For instance, Carletti and Leonello (2012) argue that competitive banks may have to keep higher liquidity reserves than banks with lower market power. If banks decrease the prices of their products, they will get lower profit, and hence they cannot afford funding sources with higher cost.

After reviewing the alternative views on the relationship between bank competition and stability, one can conclude that the influence and the direction of this influence of competition on credit risk and liquidity risk is an empirical question. Therefore, this paper aims at investigating whether there is a trade-off between competition and stability in the banking sector of Jordan and the direction of this trade-off. This study use the Lerner index in order to estimate competition of the banking sector on Jordan using data for all listed banks in the Amman Stock Exchange (ASE) with available financial data for the period 2000-2014. Lerner Index measures the divergence between the price and marginal cost (relative to price). This index is considered a bank-level and time-varying proxy for market power as it allows market power to be estimated at a bank level at each point in time (Lerner, 1934).

Little research has been done on the implications of competition regarding credit and liquidity risk. Most of the empirical studies analyze the effects of bank competition on one measure of financial stability, at most the credit risk of their loan portfolios, while few studies have considered the possible implications for bank liquidity (Almarzoqi et al., 2015). This paper assesses the impact of competition on two dimensions of stability, credit risk and liquidity risk. Jordan is an interesting context to study for number of reasons. Firstly, as stated by Beck (2013), the issue of competition is one of the areas in which future research on financial development and credit markets is needed in emerging countries. Secondly little research has been done in measuring the competition of banks using direct approaches not only for Jordan but for emerging and developing countries as well, since these measures are hard to estimate due to the lack of detailed data. Finally studying the Jordanian context could provide more informed guidance on policies related to bank competition and contestability in Jordan and other similar countries as well. By studying the behavior of banks and their riskiness in face of competitive pressure that could change the behavior of lenders and borrowers, we believe that this will provide an analytical base to provide more informed guidance on policies related to bank competition and contestability in Jordan and other similar countries as well.

Therefore, the study objectives relate to measuring, and investigating the relationship between the competition and stability of the banking sector of Jordan through evaluating the impact of competition measured by Lerner index on bank's credit and liquidity risks.

\section{Literature Review}

\subsection{Competition and Credit Risk}

This section provides an overview of the literature regarding the influence of bank competition on the incentives of banks to take risky actions. Based on "Competition Fragility View" view, too much competition may lead to excessive risk taking as it reduces profit margins (Marcus, 1984; Keeley, 1990; and Allen and Gale, 2004). This view assumes that banks decide over the risk level of their portfolios depending on bank profits, capital and reserves. When competition is high, reserves and profits are low and thus, banks are tempted to assume excessive risks. Hellman et al. (2000) argue that in an environment with greater competition, the pressure on profits will make banks choose riskier portfolios, leading to greater fragility. Dell'Ariccia and Marquez (2004) show that more intense competition may induce banks to switch to more risky, and invest on opaque borrowers. Others argue that in a more competitive environment, banks earn lower rents which also reduce their incentives for monitoring (Boot \& Thakor, 1993, Allen \& Gale, 2000). Hauswald and Marquez (2006) show that competition leads banks to acquire less information about borrowers. However, based on "Competition Stability View" higher competition may increase stability. Competition leads to reduction in lending rates, which in turn leads to reduction in the probability of default on bank credit portfolio because lower lending costs improve the credit status for borrowers (Boyd \& De Nicolò, 2005). 


\subsection{Competition and Liquidity Risk}

The relationship between competition and liquidity risk has not been widely explored in the literature. Carletti and Leonello (2012) model the portfolio allocation problem of banks between reserves or loans and, in particular, examine the ability of banks to withstand liquidity shocks. They explain that under market competition with higher intensity banks keep enough reserves, while in the presence of market power some banks default with higher probability.

\subsection{Empirical Findings on Competition and Stability}

There are numerous studies that examine the impact of competition on stability using macro-level data measures (Schaeck, et al., 2006). However, in this section will review studies that use data on an individual bank level on an international, regional and national levels.

Deniz et al. (2014) used a sample of 1,872 publicly traded banks in 63 countries over the period 1997 to 2009 . They investigate the impact bank market power on systemic stability. Their study's results consistent with the view that greater competition encourages banks to take on more diversified risks, making the banking system less fragile to shocks. Berger et al. (2009) study competition and financial stability in 23 developed countries by testing the impact of market structure on the risk potential of 8,235 banks. The authors use NPL and Z-Index and equity to total assets ratio to proxy banking system stability and Lerner index and HHI based on deposits and loans as a proxy for market power and concentration respectively. Their results suggest that banks with a greater degree of market power also have less overall risk exposure which is consistent with the traditional "Competition Fragility" view. Conversely, Boyd et al. (2009) find that competition is negatively correlated with loan losses for banks both in the US and in 134 non-industrialized countries.

Soedarmono and Tarazi (2016) from a sample of commercial banks in the Asia-Pacific region over the 19942009 period, show that banks in less competitive markets exhibit lower loan growth and higher instability. Hope et al., (2013) explore the relationship between bank competition and financial sector stability using 2005-2010 data for 10 African countries, the study regress bank stability indices on bank competition indices. They find positive relationship between market power and financial stability, they suggest that there is a trade-off between bank competition and financial sector stability as per the competition-fragility view in these countries. Using Non-Performing Loans (NPLs) as a measure of credit risk, Yeyati and Micco (2007) find an increase in NPLs as bank competition increase in eight Latin American countries.

Olga and Mira (2013) analyze the impacts of market power of banks on credit risk and the stability of the banking system in Kazakhstan. They used Lerner Index to measure banking market power, overdue loans to total bank loans ratio to estimate credit risk, Z-score index to measure overall bank stability. Their results suggest that increased market power is negatively associated with credit risk by banks. At the same time, increasing of market power has a significant positive impact on bank stability. Jiménez, et al. (2007) find for a sample of Spanish banks for the period 1988 to 2003 that banks with higher market power, as measured by the Lerner index, have lower non-performing loans, thus providing evidence for the charter value hypothesis. Similar evidence from Spain is reported by Salas and Saurina (2003).

The evidence from Jordan on this particular topic is almost non-existent and the evidence from MENA region is confined to one study by Almarzoqi et al. (2015). The authors analyze the effects of bank competition measured by Lerner index on financial stability through multiple dimensions: solvency, liquidity and credit risk. The results of their study showed that bank competition may affect financial stability in different ways, depending on the type of risk. Specifically, an increase pricing competition shows a significant and positive impact on liquidity, while it may have negative effects on bank solvency and on asset quality.

\section{Methodology}

\subsection{Sample and Data Sources}

The sample of the study includes all Jordanian banks listed in the Amman Stock Exchange (ASE) with available bank-level financial data for the period 2000-2014. The sample contains (15) banks distributed as follows: (11) commercial, (2) Islamic, and (2) investment banks operating over the study period. The study allows banks to enter and leave the sample and hence the study had a final unbalanced sample of (225) observations.

Financial data are collected mainly from the ASE Companies Guide. The ASE Companies Guide is a year book published annually by the ASE which includes detailed financial data extracted from listed companies' financial statements. In addition, some data that are not contained in the ASE Companies Guide are hand-collected or obtained using the Bank scope database. Finally, macroeconomic data are collected by using the published data on Central Bank of Jordan website. 


\subsection{Methodology and Variables}

To examine the impact of banking competition measured by the Lerner index of market power on two main dimensions of banking stability namely credit and liquidity risk, we estimate the following panel regression by using bank's fixed effects in the main analysis:

$$
\begin{array}{r}
\text { Credit Riskit }=\alpha i+\beta 1 \text { Lerner-Indexit }+\sum \lambda j X j i t+\sum \eta m Z m t+\varepsilon i t \\
\text { Liquidity Riskit }=\alpha i+\beta 1 \text { Lerner-Indexit }+\sum \gamma \mathrm{kYkit}+\sum \eta \mathrm{mZmt}+\varepsilon i t
\end{array}
$$

Where $i$ indicates bank and $t$ denotes year and $\alpha$ i denotes bank-level fixed effects. $\mathbf{X}$ represents the matrix of control variables (bank-level balance sheet variables) for each model (these variables are defined in section 3.2.3). $\mathrm{Z}$ represents the macroeconomic (these variables are defined in section 3.2.4).

\subsubsection{Dependent Variables (Banking Stability Dimensions)}

In this paper we consider two dimensions of financial stability at the individual bank level: the credit risk of the asset portfolio, and the liquidity risk. The dependent risk variables are defined as follows:

Credit Risk: Following (Dick, 2006; Farazi, Feyen, \& Rocha, 2011) we employ the ratio of provisions of credit facilities to total credit facilities extended by a bank as a proxy for Non-Performing Loans (NPL) ratio (NPL to total loans). A higher value of this ratio indicates a riskier loan portfolio of a bank and less quality of assets.

Liquidity Risk: We use two measures of liquidity risk. The first measure is total liquid assets to total deposits ratio. This ratio measures the size of the liquid assets buffer a bank has at its disposal, an increase in this ratio would mean an improvement in the liquidity position of a bank, while a reduction would imply an increase in a bank liquidity risk. The second measure is the ratio of total liquid assets to total assets, this ratio measures the size of assets that can easily converted to cash to total assets, increase in this ratio mean an improvement in the liquidity of a bank. (Demirguc-Kunt, 1990; Gonzalez-Hermosillo, 1999)

\subsubsection{Independent Variable (Bank Competition)}

The Lerner Index is a frequently used measure of market power in banking. It is defined as the difference between output prices and marginal costs (relative to prices). The advantage of the Lerner Index is that it is not a long-run equilibrium measure of competition. Also the Lerner index can be calculated at each point in time and it allows market power to be estimated at a bank level. However, the main problem with this measure is that it is hard to collect the necessary data of prices and costs. The Lerner index represents the mark-up of price over marginal costs and is an indicator of the degree of market power. It is a "level" indicator of the proportion by which price exceeds marginal cost. The Lerner index is calculated as:

$$
\text { Lerner }_{i t}=\frac{P_{i t}-M C_{i t}}{P_{i t}}
$$

Where $\mathbf{P}$ is the market price set by the firm and $\mathbf{M C}$ is the firm's marginal cost. Prices are calculated as total bank revenue on assets, the marginal costs are captured from an estimated translog cost function with respect to output. Following the approach in Fernandez de Guevara et al. (2005, 2007), Berger et al. (2009) and Demirguc-Kunt and Peria (2010), we calculate the marginal cost MC by taking the first derivative from a translog cost function as specified in equation below:

$$
\begin{array}{r}
\ln \left(C_{i t}\right)=a_{0 i}+\beta_{0} \ln \left(Q_{i t}\right)+\beta_{1} 0.5\left[\ln \left(Q_{i t}\right)\right]^{2}+a_{1} \ln \left(W 1_{i t}\right)+a_{2} \ln \left(W 2_{i t}\right)+a_{3} \ln \left(W 3_{i t}\right)+ \\
\beta_{2} 0.5 \ln \left(Q_{i t}\right) \ln \left(W 1_{i t}\right)+\beta_{3} 0.5\left[\ln \left(Q_{i t}\right) \ln \left(W 2_{i t}\right)\right]+\beta_{4} 0.5 \ln \left[\left(Q_{i t}\right) \ln \left(W 3_{i t}\right)\right]+a_{4} \ln \left(W 1_{i t}\right) \ln \left(W 2_{i t}\right)+ \\
a_{5} \ln \left(W 1_{i t}\right) \ln \left(W 3_{i t}\right)+a_{6} \ln \left(W 2_{i t}\right) \ln \left(W 3_{i t}\right)+a_{7} 0.5\left[\ln \left(W 1_{i t}\right)\right]^{2}+a_{8} 0.5\left[\ln \left(W 2_{i t}\right)\right]^{2}+ \\
a_{9} 0.5\left[\ln \left(W 3_{i t}\right)\right]^{2}+\varepsilon_{i t}
\end{array}
$$

Where $i$ denotes banks and $t$ denotes years. $\mathbf{C}$ is total operating plus financial costs, $\mathbf{Q}$ is total assets, $\mathbf{W} \mathbf{1}$ is the ratio of interest expenses to total deposits (proxy for input price of deposits), W2 is the ratio of personnel expenses to total assets (proxy for input price of labor) and $\mathbf{W} \mathbf{3}$ is the ratio of other operating and administrative expenses to total assets (proxy for input price of equipment/fixed capital).

Then the marginal cost (MC) is computed using the following equation:

$$
M C_{i t}=\frac{C_{i t}}{Q_{i t}}\left(\beta_{0}+\beta_{1} \ln Q_{i t}+\beta_{2} \ln W 1_{i t}+\beta_{3} \ln W 2_{i t}+\beta_{4} \ln W 3_{i t}\right)
$$

Greater values of the Lerner index reflect less bank competition. The index ranges from a high of 1 to a low of 0 . For a perfectly competitive firm (where $\mathrm{P}=\mathrm{MC}$ ), $\mathrm{L}=0$; a bank has no market power. Appendix 1 reports the 
estimated results of the first derivative of the translog cost function that is specified in equation (2) using the fixed effect estimator. Finally, it is important to note that we estimated the Lerner Index twice. At first the Lerner Index is estimated using all banks in the sample. In addition, it is also estimated using commercial and investment banks only excluding the two Islamic banks. This procedure is carried to check the impact without the Islamic banks.

\subsubsection{Bank-Level Control Variables}

Following Almarzoqi, et al. (2015) we include a set of control variables defined below in equations (1) and (2). The covariates $\mathrm{X}_{j}$ in equations (1) include Return on Average Equity (ROE), defined as the ratio of bank net income to the value of equity, and the Growth Rate of Total Assets. The covariates $\mathrm{Y}_{k}$ in equation (2) include Non-Interest Income Ratio, defined as the ratio of non-interest income to total revenues, Return on Average Assets (ROA), and Provisions of Credit Facilities to Total Credit Facilities. Banks with a larger proportion of non-interest income ratio may need to hold less liquidity than other banks because they depend more on non interest activates and go away from intermediation-based activities which need more liquidity, also intermediation-based activities subject to credit and interest risk, banks shifting to non interest earning activates to reduce income volatility (Hoggarth et al., 1998). The covariates $Z_{m}$ in equations (1) and (2) include macroeconomic control variables defined in section (3.2.4) below. In addition, we calculate the market share of a given bank as a control variable in order to compare the effects of market power with market concentration on the two dimensions of the banking stability (Claessens \& Laeven, 2004). Market share is calculated as total assets of a bank to the total assets of all banks ratio in the sample where higher value of market share means larger market share of a bank to its market.

\subsubsection{Macroeconomic Control Variables}

Macroeconomic factors are considered to play an important role on financial stability (Demirguç-Kunt \& Detragiache, 1998; Llewellyn, 2002), the recent financial crises paid the attention of huge number of economist to study the macroeconomic variables in the same time and before the crises to see these factors trigger the crises or not (De Grauwe, 2008; Laeven \& Valencia, 2008, 2010). More specifically, adverse economic conditions, where growth is low or negative, high interest rates and high inflation rate, are favorable to banking crises and instability (Demirguç-Kunt \& Detragiache, 1998).

Therefore, this paper controls for business cycle conditions by introducing the lagged values of the annual real Gross Domestic Product (GDP) growth rate, since the credit risk tends to increase when the economic environment deteriorates, and raising their non-performing loans, because of that banks increase their loan loss provisions and insure that they have enough liquidity to cover defaulted loans.

Also this study controls for Real Interest Rate (RIR) calculated as the nominal interest rates minus the inflation rate based on the Consumer Price Index (CPI). Higher value of RIR may decrease the credit risk and raise their non-performing loans, because higher interest rate weaken borrowers' ability to service their debt, and may need the banks to increase their loan loss provisions and insure that they have enough liquidity to cover defaulted loans.

\subsection{Data Description}

The data used to estimate the Lerner Index is presented in the next table; it reports the descriptive statistics for the inputs and the estimated values of the Lerner index for our bank sample during the period 2000-2014. also the table shows the descriptive statistics for the different variables used to estimate the marginal cost from equations (4) and (5).

Table 1. Summary statistics for inputs used to estimate the lerner index

\begin{tabular}{llllll}
\hline Variable & Obs & Mean & Std. Dev. & Min & Max \\
\hline Gross interest revenues to total asset (P) & 225 & 0.050 & 0.013 & 0.011 & 0.079 \\
Interest expenses to total deposits (W1) & 225 & 0.033 & 0.014 & 0.008 & 0.079 \\
Personnel expenses to total assets (W2) & 225 & 0.010 & 0.004 & 0.003 & 0.041 \\
Other operating and administrative expenses to total assets (W3) & 225 & 0.006 & 0.003 & 0.000 & 0.015 \\
Log of total assets (Size) & 225 & 20.823 & 1.170 & 17.793 & 23.976 \\
\hline
\end{tabular}

Table 2 below shows the summary statistics of regression variables. The data shows limited variability in relation to the mean. 
Table 2. Summary statistics of regression variables

\begin{tabular}{|c|c|c|c|c|c|c|}
\hline VARIABLES & & Mean & Variance & Std. Dev. & Min & Max \\
\hline \multirow[t]{3}{*}{ BANK COMPETITION } & Lerner Index & 0.492 & 0.012 & 0.108 & 0.094 & 0.729 \\
\hline & Lerner Index without Islamic Banks & 0.416 & 0.015 & 0.121 & -0.038 & 0.692 \\
\hline & Market Share Ratio & 0.067 & 0.017 & 0.131 & 0.002 & 0.647 \\
\hline BANK CREDIT RISK & $\begin{array}{l}\text { Provisions of Credit Facilitates to Total Credit } \\
\text { Facilities }\end{array}$ & 0.116 & 0.027 & 0.165 & 0.005 & 1.596 \\
\hline \multirow[t]{2}{*}{ BANK LIQUIDITY } & Liquid Assets to Total Deposits & 0.445 & 0.024 & 0.156 & 0.084 & 1.262 \\
\hline & Liquid Assets to Total Assets & 0.335 & 0.013 & 0.113 & 0.068 & 0.598 \\
\hline BANK BALANCE SHEET & Growth Rate of Total Assets & 0.123 & 0.023 & 0.151 & -0.551 & 0.884 \\
\hline \multirow[t]{3}{*}{ VARIABLES } & Return on Equity & 0.103 & 0.004 & 0.067 & -0.255 & 0.39 \\
\hline & Return on Assets & 0.012 & 0 & 0.009 & -0.055 & 0.038 \\
\hline & Non-Interest Income Ratio & 0.611 & 0.019 & 0.137 & 0.209 & 1.066 \\
\hline MACROECONOMIC & GDP Growth Rate & 5.228 & 5.037 & 2.244 & 2.312 & 8.559 \\
\hline VARIABLES & Real Interest Rate & 5.327 & 9.702 & 3.115 & 0.461 & 13.237 \\
\hline
\end{tabular}

Table 3 presents the pairwise correlation coefficients between the variables. There is a significant negative relationship at $5 \%$ level between the measure of bank market power (Lerner index) and the proxy of credit risk. Therefore, simple correlation analysis suggests a negative relationship between market power and credit risk. Lower values of Lerner index (indicating higher competition) are correlated with more credit risk. In addition, the table also shows a negative but insignificant correlation between Lerner index and the two measures of bank liquidity. Lower values of Lerner index are correlated with higher values of bank liquidity position. In other words more bank competition enhances liquidity position of banks. In terms of the correlation between market share ratio with the two dependent risk factors variables credit and liquidity risk, the correlation coefficients is weak as shown in the Table.

Bank profitability is positively related to the market power indicator (Lerner index) but is not correlated with concentration (market share ratio). Also, bank profitability is negatively correlated with bank credit risk. In terms of the macroeconomic control variables growth rate of total assets of banks is, as expected, positively correlated with the GDP growth rate and negatively correlated with RIR. Also the correlation coefficients between GDP growth rate and RIR with liquidity position of banks are positive and significant. However, the correlation coefficients between GDP growth rate and RIR with credit risk are weak.

Table 3. Pairwise correlation matrix of the variables

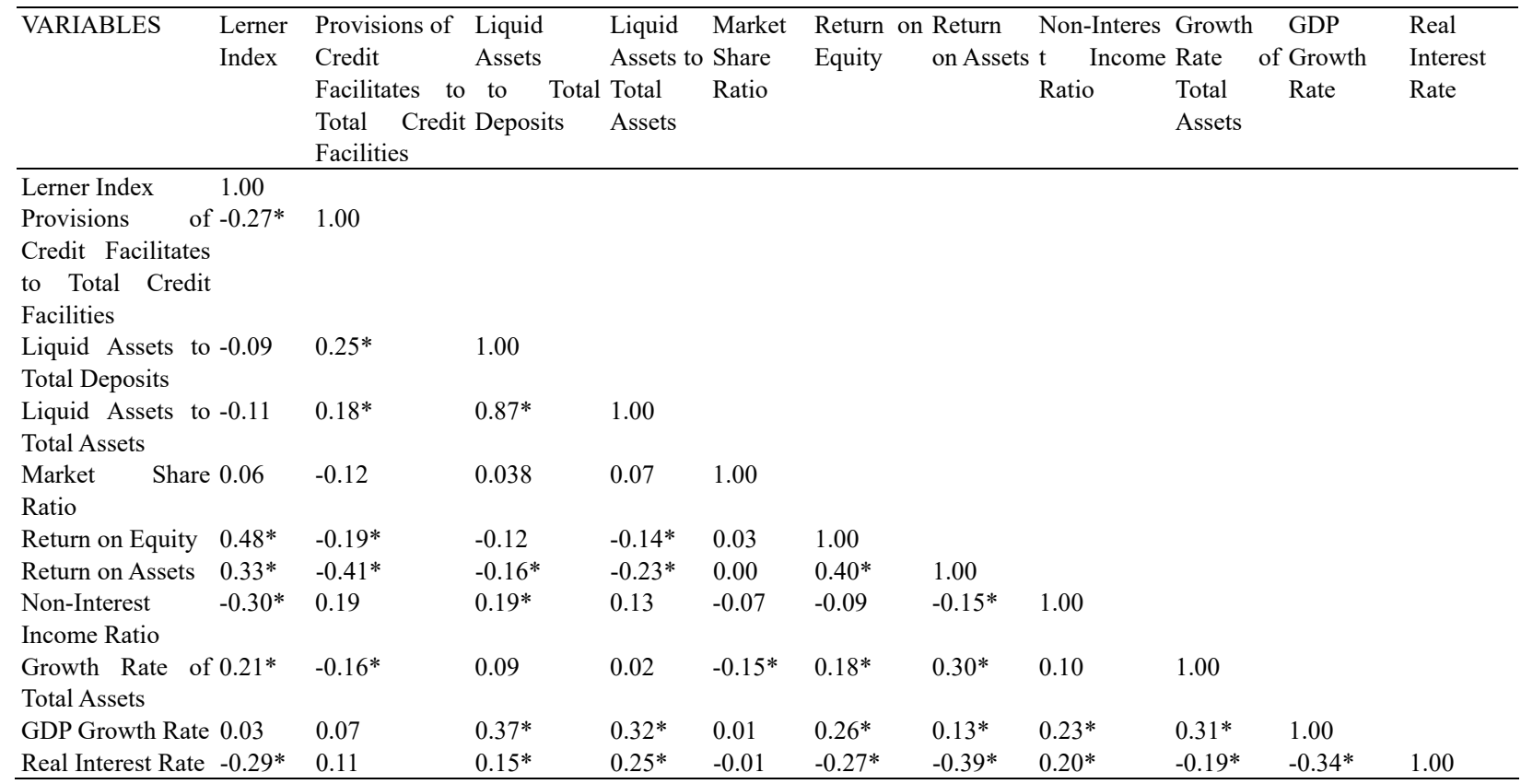

Note. * Significant at $5 \%$ level. 


\section{Empirical Results}

4.1 Results of Estimating the Lerner Index

As mentioned before we firstly estimated the first derivative of the translog cost function that specified in equation (4) using the fixed effect estimator to computing the marginal cost (MC). Table below reports the coefficients that used to computing MC.

Table 4. Estimation results of translog cost function

\begin{tabular}{|c|c|}
\hline Variable & Coefficient \\
\hline \multirow[t]{2}{*}{$\ln \left(Q_{i t}\right)$} & $1.220 * * *$ \\
\hline & $(0.247)$ \\
\hline \multirow[t]{2}{*}{$0.5\left[\ln \left(Q_{i t}\right)\right]^{2}$} & 0.003 \\
\hline & $(0.014)$ \\
\hline \multirow[t]{2}{*}{$\ln \left(\mathrm{W} 1_{\text {it }}\right)$} & 0.282 \\
\hline & $(0.253)$ \\
\hline \multirow[t]{2}{*}{$\ln \left(\mathrm{W} 2_{\mathrm{it}}\right)$} & $0.997 *$ \\
\hline & $(0.419)$ \\
\hline \multirow[t]{2}{*}{$\ln \left(\mathrm{W} 3_{\mathrm{it}}\right)$} & $0.178^{*}$ \\
\hline & $(0.083)$ \\
\hline \multirow[t]{2}{*}{$0.5 \ln \left(\mathrm{Q}_{\mathrm{it}}\right) * \ln \left(\mathrm{W} 1_{\mathrm{it}}\right)$} & 0.046 \\
\hline & $(0.024)$ \\
\hline \multirow[t]{2}{*}{$0.5 \ln \left(\mathrm{Q}_{\mathrm{it}}\right) * \ln \left(\mathrm{W} 2_{\mathrm{it}}\right)$} & 0.077 \\
\hline & $(0.045)$ \\
\hline \multirow[t]{2}{*}{$0.5 \ln \left(\mathrm{Q}_{\mathrm{it}}\right) * \ln \left(\mathrm{W} 3_{\mathrm{it}}\right)$} & -0.009 \\
\hline & $(0.007)$ \\
\hline \multirow[t]{2}{*}{$\ln \left(\mathrm{W} 1_{\mathrm{it}}\right) * \ln \left(\mathrm{W} 2_{\mathrm{it}}\right)$} & 0.008 \\
\hline & $(0.024)$ \\
\hline \multirow[t]{2}{*}{$\ln \left(\mathrm{W} 1_{\mathrm{it}}\right) * \ln \left(\mathrm{W} 3_{\mathrm{it}}\right)$} & -0.005 \\
\hline & (0.009) \\
\hline \multirow[t]{2}{*}{$\ln \left(\mathrm{W} 2_{\mathrm{it}}\right) * \ln \left(\mathrm{W} 3_{\mathrm{it}}\right)$} & -0.021 \\
\hline & $(0.017)$ \\
\hline \multirow[t]{2}{*}{$\mathrm{a} 70.5\left[\ln \left(\mathrm{W} 1_{\mathrm{it}}\right)\right]^{2}$} & $0.108^{*}$ \\
\hline & $(0.043)$ \\
\hline \multirow[t]{2}{*}{$0.5\left[\ln \left(\mathrm{W} 2_{\mathrm{it}}\right)\right]^{2}$} & $0.339 * * *$ \\
\hline & $(0.048)$ \\
\hline \multirow[t]{2}{*}{$0.5\left[\ln \left(\mathrm{W} 3_{\mathrm{it}}\right)\right]^{2}$} & $0.021^{* * *}$ \\
\hline & $(0.005)$ \\
\hline \multirow[t]{2}{*}{ Constant } & -0.958 \\
\hline & (2.507) \\
\hline R-squared & 0.991 \\
\hline
\end{tabular}

Notes. Standard errors in parentheses.

* significant at $10 \%$ level; ** significant at $5 \%$ level;*** significant at $1 \%$ level.

Then, the researchers calculated the Lerner index for each bank in each year from 2000-2014. The values of Lerner range between 0.22 and 0.80 with an average equal to 0.55 , which indicates the level of bank competition in Jordan is monopolistic. Table 5 below shows descriptive statistics for the market power index (Lerner Index).

Table 5. Descriptive statistic for the estimated marginal cost and the lerner index

\begin{tabular}{llllll}
\hline Variable & Observations & Mean & Std. Dev. & Min & Max \\
\hline Marginal Cost & 225 & 0.033 & 0.010 & 0.011 & 0.081 \\
Lerner Index & 225 & 0.492 & 0.108 & 0.094 & 0.729 \\
\hline
\end{tabular}

The average Lerner index for the periods 2000-2004, 2005-2009, and 2010-2014 are 0.53, 0.42, and 0.49, 
respectively. The maximum average value of Lerner index was in 2003 where it was 0.59 and the minimum was in 2008 with value of 0.39 .

The average Lerner index (market power) that has been estimated for all banks is about 0.49 . The average Lerner index estimated after excluding the Islamic banks is 0.416 , which is close to the sample average. The commercial banks have the most shares of the market based on total assets as the market share ratios for commercial, investment, and Islamic are $0.868,0.044$, and 0.088 respectively in 2014 .

From examining the level of bank competition in Jordan using the Lerner Index, we can conclude that monopolistic competition is the best description of competitive structure in banking industry.

\subsection{Competition and Credit Risk}

Table 6 below shows the empirical results of the credit risk model presented earlier in equation number (1) in Section (3). The empirical results using fixed and random effects estimations are presented in columns (1) and (2) respectively. The results show that the credit risk of banks is significantly affected by bank competition measured by Lerner index, after controlling for bank-level and macroeconomic variables that may affect the credit risk of banks. The negative 0.315 coefficient of Lerner index implies that higher market power (less bank competition) is associated with higher credit risk. To test the impact of market concentration on the competition-credit risk relationship, we introduce the market share in Models 3 and 4 as a control variable. The findings indicate that there is no significant relationship between the concentration measured by the market share ratio and credit risk. In addition, the results of competition-credit risk have not changed.

In terms of other control variables, the results indicate that there is a significant positive relationship between credit risk and RIR, which implies that higher RIR leads to higher credit risk.

Table 6. The effects of bank competition on credit risk

\begin{tabular}{lllll}
\hline The Dependent Variable (Credit Risk) & & & \\
VARIABLES & $\begin{array}{l}\text { Model 1 } \\
\text { (fixed effects) }\end{array}$ & $\begin{array}{l}\text { Model 2 } \\
\text { (random effects) }\end{array}$ & $\begin{array}{l}\text { Model 3 } \\
\text { (fixed effects) }\end{array}$ & $\begin{array}{l}\text { Model } 4 \\
\text { (random effects) }\end{array}$ \\
\hline Lerner Index ${ }^{1}$ & $-0.315^{*}$ & $-0.367^{* *}$ & $-0.319^{*}$ & $-0.356^{* *}$ \\
& $(0.14)$ & $(0.13)$ & $(0.14)$ & $(0.13)$ \\
ROE & 0.306 & 0.235 & 0.317 & 0.226 \\
& $(0.21)$ & $(0.21)$ & $(0.21)$ & $(0.21)$ \\
Growth Rate of & $-0.225^{* *}$ & $-0.208^{* *}$ & $-0.223^{* *}$ & $-0.215^{* *}$ \\
Total Assets & $(0.07)$ & $(0.07)$ & $(0.07)$ & $(0.07)$ \\
Lagged GDP & -0.00323 & -0.00522 & -0.00335 & -0.00814 \\
& $(0.01)$ & $(0.5)$ & $(0.01)$ & $(0.5)$ \\
RIR & $0.0144^{* *}$ & -0.00578 & $0.0144^{* *}$ & -0.00546 \\
Market Share Ratio & $(0.01)$ & $(0.03)$ & $(0.01)$ & $(0.03)$ \\
Constant & - & - & -0.496 & -0.2 \\
R-squred & & & $(0.48)$ & $(0.16)$ \\
N & $0.207^{*}$ & 0.305 & $0.241^{*}$ & 0.321 \\
F-Statistc & $(0.1)$ & $(1.22)$ & $(0.1)$ & $(1.22)$ \\
Wald chi2 & 0.274 & & 0.279 & 225 \\
Prob > F & 225 & 225 & 225 & 70 \\
\hline
\end{tabular}

Note. ${ }^{*}$ significant at $5 \%$ level; $* *$ significant at $1 \%$ level. ${ }^{1}$ all banks in our sample entered in the estimation of calculating the Lerner index.

To test the influence of Islamic banks on our results, we re-estimate the four models presented in Table 6 after excluding the two Islamic banks from our sample and present the findings in Table 7. The empirical results are qualitatively the same. This result indicates that credit risk of conventional banks is influenced by the same set of variables as in of Islamic banks. 
Table 7. The effects of bank competition on credit risk after excluding Islamic banks

\begin{tabular}{|c|c|c|c|c|}
\hline \multicolumn{5}{|c|}{ The Dependent Variable (Credit Risk) } \\
\hline VARIABLES & $\begin{array}{l}\text { Model } 1 \\
\text { (fixed effects) }\end{array}$ & $\begin{array}{l}\text { Model } 2 \\
\text { (random effects) }\end{array}$ & $\begin{array}{l}\text { Model } 3 \\
\text { (fixed effects) }\end{array}$ & $\begin{array}{l}\text { Model } 4 \\
\text { (random effects) }\end{array}$ \\
\hline \multirow[t]{2}{*}{ Lerner Index ${ }^{2}$} & $-0.320 *$ & $-0.345 * *$ & $-0.329 *$ & $-0.341 * *$ \\
\hline & $(0.13)$ & $(0.13)$ & $(0.13)$ & $(0.13)$ \\
\hline \multirow[t]{2}{*}{ ROE } & 0.124 & 0.0592 & 0.132 & 0.0476 \\
\hline & $(0.23)$ & $(0.22)$ & $(0.23)$ & $(0.22)$ \\
\hline \multirow[t]{2}{*}{ Growth Rate of Total Assets } & $-0.236 * *$ & $-0.221 * *$ & $-0.232 * *$ & $-0.228 * *$ \\
\hline & $(0.08)$ & $(0.08)$ & $(0.08)$ & $(0.08)$ \\
\hline \multirow[t]{2}{*}{ Lagged GDP } & -0.00507 & 0.0141 & -0.00507 & 0.0124 \\
\hline & $(0.01)$ & $(0.54)$ & $(0.01)$ & $(0.54)$ \\
\hline \multirow[t]{2}{*}{ RIR } & $0.0154^{*}$ & -0.00803 & $0.0155^{*}$ & -0.00785 \\
\hline & $(0.01)$ & $(0.03)$ & $(0.01)$ & $(0.03)$ \\
\hline \multirow[t]{2}{*}{ Market Share Ratio } & - & - & -0.583 & -0.25 \\
\hline & & & $(0.49)$ & $(0.18)$ \\
\hline \multirow[t]{2}{*}{ Constant } & $0.217^{*}$ & 0.253 & $0.261^{* *}$ & 0.274 \\
\hline & $(0.09)$ & $(1.32)$ & $(0.1)$ & $(1.31)$ \\
\hline R-squred & 0.324 & - & 0.33 & - \\
\hline $\mathrm{N}$ & 181 & 181 & 181 & 181 \\
\hline F-Statistc & 6.05 & - & 5.47 & - \\
\hline Wald chi2 & - & 74.22 & - & 76.71 \\
\hline Prob $>$ F & 0.000 & 0.000 & 0.000 & 0.000 \\
\hline
\end{tabular}

From the regression analysis for the first dimension of banking stability (credit risk), the empirical results suggest that decrease in the Lerner index which means increase in competition implies an increase in the ratio of provisions of credit facilitates to total credit facilities (a proxy for nonperforming loans to total credit ratio). This finding indicates that more competition in the banking sector of Jordan leads to more risk taking from the banks.

\subsection{Competition and Liquidity Risk}

Table 8 shows the estimated results of the liquidity risk model presented earlier in equation number (2). The regression estimates the impact of market power on two measures of liquidity: liquid assets to total assets and liquid assets to total deposits for all banks in our sample using the fixed effects model. The estimated results suggest that there is no impact of bank competition measured by Lerner index on liquidity position of banks. As the results in Table 8 shows, the results of the four reported models show that there is no significant relationship between the two measures of liquidity and Lerner indices. These results are robust to the introduction of the market share in Models 2 and 4 as a control variable. In addition, the results indicate that and there is no significant relationship between the concentration measured by the market share ratio and liquidity risk.

The estimated results of macroeconomic control variables have a significant impact on bank liquidity as control variables. The coefficient of lagged GDP growth rate and RIR suggest that an increase in these variables enhance the liquidity position of banks. 
Table 8 . The effects of bank competition on liquidity risk

\begin{tabular}{|c|c|c|c|c|}
\hline \multicolumn{5}{|l|}{ The Dependent Variable (Liquidity Position) } \\
\hline \multirow[t]{2}{*}{ VARIABLES } & \multicolumn{2}{|c|}{ Liquid Assets to Total Assets } & \multicolumn{2}{|c|}{ Liquid Assets to Total Deposits } \\
\hline & Model 1 & Model 2 & Model 3 & Model 4 \\
\hline \multirow[t]{2}{*}{ Lerner Index ${ }^{1}$} & -0.0114 & -0.0127 & -0.0945 & -0.0946 \\
\hline & $(0.11)$ & $(0.11)$ & $(0.08)$ & $(0.08)$ \\
\hline \multirow[t]{2}{*}{ ROA } & 1.55 & 1.57 & 0.228 & 0.229 \\
\hline & $(1.27)$ & $(1.27)$ & $(0.86)$ & $(0.87)$ \\
\hline \multirow{2}{*}{$\begin{array}{l}\text { Provisions of Credit Facilitates to Total } \\
\text { Credit Facilities }\end{array}$} & $0.220^{* *}$ & $0.216^{* *}$ & 0.0574 & 0.0572 \\
\hline & $(0.07)$ & $(0.07)$ & $(0.05)$ & $(0.05)$ \\
\hline \multirow[t]{2}{*}{ Non-Interest Income Ratio } & 0.0414 & 0.0442 & -0.0116 & -0.0114 \\
\hline & $(0.1)$ & $(0.1)$ & $(0.07)$ & $(0.07)$ \\
\hline \multirow[t]{2}{*}{ Lagged GDP } & $0.0204 *$ & $0.0204 *$ & $0.0197 * *$ & $0.0197 * *$ \\
\hline & $(0.01)$ & $(0.01)$ & $(0.01)$ & $(0.01)$ \\
\hline \multirow[t]{2}{*}{ RIR } & $0.0210 * *$ & $0.0210^{* *}$ & $0.0170^{* *}$ & $0.0170^{* *}$ \\
\hline & $(0.01)$ & $(0.01)$ & $(0)$ & $(0)$ \\
\hline \multirow[t]{2}{*}{ Market Share Ratio } & - & -0.338 & - & -0.0233 \\
\hline & & $(0.4)$ & & $(0.27)$ \\
\hline \multirow[t]{2}{*}{ Constant } & 0.169 & $0.191 *$ & $0.197 * *$ & $0.198 * *$ \\
\hline & $(0.09)$ & $(0.1)$ & $(0.06)$ & $(0.06)$ \\
\hline R-squred & 0.435 & 0.437 & 0.489 & 0.489 \\
\hline $\mathrm{N}$ & 209 & 209 & 209 & 209 \\
\hline F-Statistic & 8.12 & 7.717 & 10.083 & 9.503 \\
\hline Prob $>$ F & 0 & 0 & 0 & 0 \\
\hline Fixed Effects & Yes & Yes & Yes & Yes \\
\hline
\end{tabular}

Note. ${ }^{*}$ significant at $5 \%$ level; $* *$ significant at $1 \%$ level. ${ }^{1}$ all banks in our sample entered in the estimation of calculating the Lerner index.

In addition, we estimate the last four models presented in Table 8 after excluding the two Islamic banks from the sample and present the results in Table 9. The results presented in Table 9 show that there is a significant negative relationship between Lerner index and liquidity position of banks measured by the ratio of liquid assets to total assets and the ratio of liquid assets to total deposits.

Table 9. The Effects of bank competition on liquidity risk after excluding Islamic banks

\begin{tabular}{|c|c|c|c|c|}
\hline \multicolumn{5}{|l|}{ The Dependent Variable (Liquidity Risk) } \\
\hline \multirow[t]{2}{*}{ VARIABLES } & \multicolumn{2}{|c|}{ Liquid Assets to Total Assets } & \multicolumn{2}{|c|}{ Liquid Assets to Total Deposits } \\
\hline & Model 1 & Model 2 & Model 3 & Model 4 \\
\hline \multirow[t]{2}{*}{ Lerner Index ${ }^{2}$} & $-0.215^{*}$ & $-0.223^{*}$ & $-0.191 * *$ & $-0.192 * *$ \\
\hline & $(0.09)$ & $(0.09)$ & $(0.07)$ & $(0.07)$ \\
\hline \multirow[t]{2}{*}{ ROA } & 0.601 & 0.639 & 0.23 & 0.237 \\
\hline & $(1.06)$ & $(1.06)$ & $(0.83)$ & $(0.83)$ \\
\hline Provisions of Credit Facilitates to Total Credit & 0.0628 & 0.0558 & 0.035 & 0.0337 \\
\hline Facilities & $(0.06)$ & $(0.06)$ & $(0.05)$ & $(0.05)$ \\
\hline \multirow[t]{2}{*}{ Non-Interest Income Ratio } & $0.354^{* *}$ & $0.365^{* *}$ & $0.319^{* *}$ & $0.321 * *$ \\
\hline & $(0.13)$ & $(0.13)$ & $(0.1)$ & $(0.1)$ \\
\hline \multirow[t]{2}{*}{ Lagged GDP } & $0.0173^{*}$ & $0.0173 *$ & $0.0123 *$ & $0.0123 *$ \\
\hline & $(0.01)$ & $(0.01)$ & $(0.01)$ & $(0.01)$ \\
\hline \multirow[t]{2}{*}{ RIR } & 0.0086 & 0.0085 & 0.0064 & 0.0064 \\
\hline & $(0.00)$ & $(0.00)$ & $(0.00)$ & $(0.00)$ \\
\hline \multirow[t]{2}{*}{ Market Share Ratio } & & -0.433 & & -0.0808 \\
\hline & & $(0.33)$ & & $(0.26)$ \\
\hline \multirow[t]{2}{*}{ Constant } & $0.178^{*}$ & $0.207 *$ & $0.123^{*}$ & $0.128 *$ \\
\hline & $(0.08)$ & $(0.08)$ & $(0.06)$ & $(0.06)$ \\
\hline R-squred & 0.512 & 0.517 & 0.527 & 0.527 \\
\hline $\mathrm{N}$ & 194 & 194 & 194 & 194 \\
\hline F-Statistic & 5.12 & 5.12 & 5.14 & 4.87 \\
\hline Prob $>F$ & 0.000 & 0.000 & 0.000 & 0.000 \\
\hline Fixed Effects & Yes & Yes & Yes & Yes \\
\hline
\end{tabular}

Notes. ${ }^{*}$ significant at $5 \%$ level; ${ }^{* *}$ significant at $1 \%$ level. ${ }^{2}$ all banks excluding Islamic banks in our sample entered in estimation of calculating the Lerner index. 
These results imply that an increase in competition improves the liquidity position of non-Islamic banks. These results support Carletti and Leonello (2012) and the recently evidence of Almarzoqi et al. (2015) who argue that banks choose to keep higher buffers of liquid assets if they are facing high competition, since these banks may get lower profit margins and are then unable to afford higher cost funding sources.

The reason behind the change of the results presented in Table (8) for the all banks sample and the ones reported in Table (9) for the sample excluding Islamic banks is that measures of liquidity position of Islamic banks are different than those for conventional banks. This is because Islamic banks may face wider mismatch between their assets and liabilities as they do not have enough financial instruments, accessible to conventional banks, to manage their liquidity. This is because these instruments, such as the discount windows and debt instruments are interest-based, and therefore, they are not Shariah compliant (Sabri Mohammad, 2013). For this reason they use their cash flows to keep large buffers of liquid assets more than the conventional banks.

Also the estimated results suggest that higher proportion of non-interest income ratio enhance liquidity of banks, since banks receiving higher proportion of their income from fees activities that may enhance liquidity of banks. However, there is no significant relationship between ROA and a provision of credit facilitates to total credit facilities ratios and liquidity position of banks.

The estimated results of business cycle improvements have a significant impact on bank liquidity. The coefficient of lagged GDP growth rate suggests that an increase in this variable enhance the liquidity position of banks. However, there is no significant relationship between RIR and liquidity measures.

In addition, the market share is introduced in models 2 and 4 as a control variable to compare the effects of market power with market concentration on the two measures of liquidity. The results show that there is no significant relationship between the concentration measured by the market share ratio and liquidity.

\section{Conclusion}

This paper examines the impact of competition measured by Lerner Index on two dimensions of financial stability: credit risk and liquidity risk. Using a dataset of all Jordanian banks, including (11) commercial, (2) Islamic, and (2) investment banks, listed in the Amman Stock Exchange with available bank-level financial data for the period 2000-2014, we estimate competition of the banking sector in Jordan through Lerner index. The analysis presented in this study shows that the state of competition of the banking sector in Jordan is monopolistic and has not changed largely over the study period. To answer the main questions of this paper, we examine the impact of competition measured by Lerner index on two main dimensions of banking stability credit and liquidity risk. The advantage of using the Lerner index is that this measure can be calculated at each point in time and it allows market power to be estimated at bank level. After controlling for bank-level control variables and macroeconomic conditions, the empirical results of the impact market power measured by Lerner index on credit risk show that an increase in price competition leads to an increase in the ratio of provisions of credit facilitates to total credit facilities which is proxy for nonperforming loans to total credit ratio. This result implies that more competition in the banking sector of Jordan leads to more risk taking from banks, which support of the Charter Value hypothesis.

The empirical results of the impact of price competition on the second dimension of banking stability liquidity risk, implies that an increase in price competition improves the liquidity position of banks. However, these results hold only for the sample of non-Islamic banks. Islamic banks may face wider mismatch between its assets and liabilities due to its inability to use conventional debt instruments offered by the market and hence it keeps larger cash buffers to compensate for this extra risk.

The empirical results suggest that the effects of banking competition on stability are different in terms of the dimension of stability. The results show that increases of price competition lead to more risk taking from banks and increase their credit risk, while banking competition enhances liquidity position of banks.

\section{Acknowledgments}

The authors would like to thank Fayez Haddad, Diana Abu Ghunmi and Thaer Qadoumi for providing useful comments, all remaining errors are ours. Special thanks to Areej Elayyan for enormous support.

\section{References}

Allen, F., \& Gale, D. (2000). Comparing Financial Systems. Cambridge, Massachusetts: MIT Press.

Allen, F., \& Gale, D. (2004). Competition and financial stability. Journal of Money Credit and Banking, 36, 453-480. https://doi.org/10.1353/mcb.2004.0038

Almarzoqi, R., Ben Naceur, S., \& Scopelliti, A. (2015). How Does Bank Competition Affect Solvency, Liquidity 
and Credit Risk? Evidence from the MENA Countries. IMF Working Paper, Working Paper, NO. 15/210. https://doi.org/10.2139/ssrn.2696068

Amidu, M., \& Wolfe, S. (2013). Does bank competition and diversification lead to greater stability? Evidence from emerging markets. Review of Development Finance, 3, 152-166. https://doi.org/10.1016/j.rdf.2013.08.002

Anginer D., Demirguc-Kunt, A., \& Zhu, M. (2014). How Does Competition Affect Bank Systemic Risk? Journal of Financial Intermediation, 23, 1-26. https://doi.org/10.1016/j.jfi.2013.11.001

Beck, T., De Jonghe, O., \& Schepens, G. (2013). Bank Competition and Stability: Cross-Country Heterogeneity. Journal of Financial Intermediation, 22, 218-244. https://doi.org/10.1016/j.jfi.2012.07.001

Beck, T., Demirgüç-Kunta, A., \& Levine, R. (2006). Bank concentration, competition, and crises: First results. Journal of Banking \& Finance, 30(5), 1581-1603. https://doi.org/10.1016/j.jbankfin.2005.05.010

Beck, T, Demirgüç-Kunt, A, \& Maksimovic, V. (2004). Bank Competition, Financing Constraints and Access to Credit. Journal of Money Credit and Banking, 363(2), 627-648. https://doi.org/10.1353/mcb.2004.0039

Beck, T. (2008). Bank Competition and Financial Stability: Friends or Foes? World Bank Policy Research Working Paper, No. 4656. https://doi.org/10.1596/1813-9450-4656

Berger, A., Demirgüç-Kunt, A., Levine, R., \& Haubrich, G. (2004). Bank Concentration and Competition: An Evolution in the Making. Journal of Money, Credit, and Banking, 36(3). https://doi.org/10.1353/mcb.2004.0040

Berger, A. N., Klapper, L. F., \& Turk-Ariss, R. (2009). Bank competition and financial stability. Journal of Financial Services Research, 35, 99-118. https://doi.org/10.1007/s10693-008-0050-7

Boot, A., \& Thakor, A. (1993). Self-Interested Bank Regulation. American Economic Review, 83, 206-2012.

Boyd, J., \& De Nicolò, G. (2005). The Theory of Bank Risk Taking Revisited. Journal of Finance, 60, 1329-1343. https://doi.org/10.1111/j.1540-6261.2005.00763.x

Boyd, J., De Nicolò, G., \& Abu, M. J. (2009). Bank Competition, Risk, and Asset Allocations. IMF Working Paper 09/143, International Monetary Fund, Washington D.C. https://doi.org/10.5089/9781451872903.001

Caminal, R., \& Matutes, C. (2002), Market power and Bank Failures. International Journal of Industrial Organization, 20, 1341-1361. https://doi.org/10.1016/S0167-7187(01)00092-3

Carletti, E., \& Leonello, A. (2012). Credit Market Competition and Liquidity Crises. EUI Working Papers, No.2012/14.

Cetorelli, N. (1999). Competitive analysis in banking: Appraisal of the methodologies. Economic Perspectives, 2-15.

Cetorelli, N. (2001). Competition among banks: Good or bad?" Economic Perspectives. Federal Reserve Bank of Chicago, 2, 38-48.

Claessens, S. (2009). Competition if the Financial Sector: Overview of Competition Policies. IMF Working Paper, Working Paper, NO. 09/45. https://doi.org/10.5089/9781451871937.001

Claessens, S., \& Laeven, L. (2004). What Drives Bank Competition? Some International Evidence. Journal of Money, Credit and Banking, 36, 563-583. https://doi.org/10.1353/mcb.2004.0044

Demirguc-Kunt, A., \& Peria, M. (2010). A framework for analyzing competition in the banking sector: An application to the case of Jordan. Policy Research Working Paper No. 5499, The World Bank. https://doi.org/10.1596/1813-9450-5499

Dell'Ariccia, G., Laeven, L., \& Deniz, I. (2008). Credit Booms and Lending Standards: Evidence from the Subprime Mortgage Market. IMF Working Paper, Working Paper No. 08/106. https://doi.org/10.5089/9781451869675.001

Dell'Ariccia, G., \& Marquez, R. (2004). Information and bank credit allocation. Journal of Financial Economics, 72, 185-214. https://doi.org/10.1016/S0304-405X(03)00210-1

Fernandez de Guevara, J., Maudos, J., \& Perez, F. (2005). Market Power in European Banking Sectors. Journal of Financial Services Research, 27, 109-137. https://doi.org/10.1007/s10693-005-6665-z

Fernandez de Guevara, J., Maudos, J., \& Perez, F. (2007). Integration and Competition in the European Financial Markets. Journal of International Money and Finance, 26, 26-45. 
https://doi.org/10.1016/j.jimonfin.2006.10.008

Hauswald, R., \& Marquez, R. (2006). Competition and Strategic Information Acquisition in Credit Markets. Review of Financial Studies, 19, 967-1000. https://doi.org/10.1093/rfs/hhj021

Hellmann, T., Kevin, M., \& Stiglitz, J., (2000). Liberalization, Moral Hazard in Banking, and Prudential Regulation: Are Capital Requirements Enough? American Economic Review, 90(1), 147-165. https://doi.org/10.1257/aer.90.1.147

Hoggarth, G., \& Saporta, V. (2001). Costs of Banking System Instability: Some Empirical Evidence. Financial Stability Review, 148-165. https://doi.org/10.2139/ssrn.276182

Hope, C., Gwatidzo, T, \& Ntuli, M. (2013). Investigating The Effect of Bank Competition on Financial Stability In Ten African Countries. International Business \& Economics Research Journal, 12(7). https://doi.org/10.19030/iber.v12i7.7968

Jackson, W. (1992). The Price-Concentration Relationship in Banking: A Comment. Review of Economics and Statistics, 74, 373-376. https://doi.org/10.2307/2109676

Jeong, H. K., \& Joh, S. W. (2011). Risk Taking of "TBTF" Banks in a Concentrated Market: Evidence from Surviving Banks after a Financial Crisis.

Jimenez, G., Lopez, J., \& Saurina, J. (2007). How Does Competition Impact Bank Risk Taking? Federal Reserve Bank of San Francisco Working Paper Series 2007-23. https://doi.org/10.24148/wp2007-23

Kaas, L. (2004). Financial market integration and loan competition. When entry deregulation is socially beneficial? European Central Bank, Working Paper No. 403. https://doi.org/10.2139/ssrn.601023

Keeley, M. C. (1990). Deposit Insurance, Risk, and Market Power in Banking. American Economic Review, 80, 1183-1200.

Lerner, A. P. (1934). The Concept of Monopoly and the Measurement of Monopoly. Review of Economic Studies, 157-175. https://doi.org/10.2307/2967480

Marcus, A. J. (1984). Deregulation and bank financial policy. Journal of Banking and Finance, 8, 557-565. https://doi.org/10.1016/S0378-4266(84)80046-1

Martinez-Miera, D., \& Repullo, R. (2010). Does Competition Reduce the Risk of Bank Failure? Review of Financial Studies, Society for Financial Studies, 23(10), 3638-3664. https://doi.org/10.1093/rfs/hhq057

Mohammad, S. (2013). Liquidity Risk Management in Islamic Banks: A Survey. Afro Eurasian Studies, Special Issue on Islamic Economics and Finance, 2(1\&2), 215-230.

Olga and Mira. (2013). The Effect of Market Power on Bank Credit Risk-Taking and Bank Stability in Kazakhstan. Transition Studies Review, 335-350. https://doi.org/10.1007/s11300-013-0297-z

Panzar, J., \& Rosse, J. (1982). Structure, conduct, and comparative statistics. Bell Laboratories Economics Discussion Paper.

Panzar, J., \& Rosse, J. (1987). Testing for monopoly equilibrium. The Journal of Industrial Economics, 35(4), 443-456. https://doi.org/10.2307/2098582

Petersen, M. A., \& Rajan, R. G. (1995). The effect of credit market competition on lending relationship. Quarterly Journal of Economics, 110, 407-443. https://doi.org/10.2307/2118445

Turk Ariss, R. (2010). On the implications of market power in banking: Evidence from developing countries. Journal of Banking and Finance, 34(4), 765-775. https://doi.org/10.1016/j.jbankfin.2009.09.004

Salas, V., \& Saurina, J. (2003). Deregulation, Market Power and Risk Behavior in Spanish Banks. European Economic Review, 47, 1061-1075. https://doi.org/10.1016/S0014-2921(02)00230-1

Schaeck, K., \& Cihak, M. (2010). Competition, Efficiency, and Soundness in Banking: An Industrial Organization Perspective. European Banking Center Discussion Paper No. 2010-20S. https://doi.org/10.2139/ssrn.1635245

Schaeck, K., Cihak, M., \& Wolfe, S. (2006). Are more competitive banking systems more stable? IMF Working Paper 06/143. https://doi.org/10.5089/9781451864038.001

Soedarmono, W., \& Tarazi, A. (2016). Competition, Financial Intermediation, and Riskiness of Banks: Evidence from the Asia-Pacific Region. Emerging Markets Finance and Trade, Taylor and Francis Journals, 52(4), 961-974. https://doi.org/10.1080/1540496X.2015.1018039 
Wagner, W. (2010). Loan market competition and bank risk-taking. Journal of Financial Services Research, 37, 71-81. https://doi.org/10.1007/s10693-009-0073-8

Vives, Z. (2001). Competition in the Changing World of Banking. Oxford Review of Economic Policy, 17, 535-545. https://doi.org/10.1093/oxrep/17.4.535

Yeyati, E. L., \& Micco, A. (2007). Concentration and Foreign Penetration in Latin American Banking Sectors: Impact on Competition and Risk. Journal of Banking and Finance, 31, 1633-1647. https://doi.org/10.1016/j.jbankfin.2006.11.003

Dick, A. (2006). Nationwide branching and its impact on market structure, quality and bank performance. Journal of Business, 79(2), 567-92. https://doi.org/10.1086/499131

Farazi, S., Feyen, E., \& Rocha, R. (2011). Bank Ownership and Performance in the Middle East and North Africa Region. World Bank Policy Research Working Paper 5620, World Bank, Washington, DC. https://doi.org/10.1596/1813-9450-5620

Hoggarth, G., Milne, A., \& Wood, G. (1998). Alternative routes to banking stability: A comparison of UK and German banking systems. Bank of England Financial Stability Review, (5), 55-68.

De Grauwe, P. (2008). The banking crisis: Causes, consequences and remedies. University of Leuven and CESifo. Mimeo.

Demirguç-Kunt, A., Detragiache, E. (1998). The Determinants of Banking Crises and Developed Countries. IMF Staff Papers, 45(1), 81-109. https://doi.org/10.2307/3867330

Laeven, L., Valencia, F. (2008). Systemic banking crises: A new database. International Monetary Fund Working Paper 08/224. https://doi.org/10.5089/9781451870824.001

Laeven, L., Valencia, F. (2010). Resolution of banking crises: The good, the bad, and the ugly. International Monetary Fund Working Paper 10/146. https://doi.org/10.5089/9781455201297.001

Llewellyn, D. (2002). An Analysis of the Causes of Recent Banking Crises. European Journal of Finance, 8, 152-175. https://doi.org/10.1080/13518470110071182

\section{Notes}

Note 1. Developing countries are defined according to their Gross National Income (GNI) per capita per year. Countries with a GNI of US\$11,905 and less are defined as developing (specified by the World Bank, 2013).

Note 2. For a review about the trade-off between stability and competition see Boyd and De Nicoló (2005), they review the empirical literature about the bank risk taking and competition, and they conclude that the evidence is best described as "mixed".

\section{Copyrights}

Copyright for this article is retained by the author(s), with first publication rights granted to the journal.

This is an open-access article distributed under the terms and conditions of the Creative Commons Attribution license (http://creativecommons.org/licenses/by/4.0/). 